\title{
Evaluation of nutritive value, fatty acid composition and lipid quality indices of freshwater catfishes and murrels
}

\begin{abstract}
The study was conducted to determine the nutritive value in terms of proximate composition, fatty acid (FA) profile and lipid quality indices off our catfish species (Wallago attu, Ompok pabda, Clarias gariepinus, Pangasidon hypophthalmus) and two murrel species (Channa striatus, Channa punctatus) from Odisha, India. Among the species investigated the maximum fillet protein $(22.35 \%)$ and lipid $(13.45 \%)$ was recorded in C. striatus and C. gariepinus, respectively. All the fish species showed a FA profile of saturated fatty acid (SFA) $>$ mono unsaturated fatty acid (MUFA) $>$ poly unsaturated fatty acid (PUFA). The n-3 PUFA distribution in the experimental species was observed as docosahexaenoic acid (DHA, 22:6 n-3)>alpha linolenic acid (ALA, 18:3 n-3)>eicosapentaenoic acid (EPA, 20:5 $\mathrm{n}-3)$ except C. gariepinus. The fillet EPA and DHA content of two murrel species and $W$. attu were similar and significantly higher $(P<0.05)$ among the species. Similarly these three species viz., W. attu, C. striatus and C. punctatus showed maximum DHA quantity in their fillet. The n-6/n-3 ratios in five species except $C$. gariepinus were below 4.0. The athrogenic index (IA) and thrombogenic index (IT) were $<1$ and cholesterolomic index $(\mathrm{h} / \mathrm{H})$ for all species were $>1$, suitable for human health. Overall, considering nutritive value, fillet protein and very essential fatty acids, the experimental species can be arranged in the following order C. Straitus $>$ C. punctatus $=$ W. attu $>$ P. Hypophthalmus $>$ O. Pabda $>$ C. gariepinus.
\end{abstract}

\author{
Volume 9 Issue 3 - 2020 \\ Chiranjiv Pradhan, ${ }^{1,2}$ Dipti Ranjan Das, ' Tapan \\ Kumar Mohanty,' Shiba Shankar Giri' \\ 'ICAR-Central Institute of Freshwater Aquaculture, \\ Kausalyaganga, India \\ ${ }^{2}$ Department of Aquaculture, Kerala University of Fisheries and \\ Ocean Studies, India
}

Correspondence: Chiranjiv Pradhan, Department of Aquaculture, Kerala University of Fisheries and Ocean Studies, Panangad, Kochi, India, Email cpradhnkufos@gmail.com

Received: May II, 2020 | Published: June 23, 2020

Keywords: catfishes, murrels, fatty acid profile, lipid quality indices

\section{Introduction}

Aquatic food products have been an integral part of the human diet since mankind started fishing the oceans and producing food through aquaculture. ${ }^{1}$ Fish is a rich source of high quality and easily digestible proteins and unsaturated fats, particularly long chain omega-3 fatty acids which play important roles in human health. Dietary fatty acids are increasingly getting high attention for their role as biological regulators. Importantly, the two series of fatty acids i.e., n-3 and n-6 polyunsaturated fatty acids (PUFA) gets utmost consideration. The most biologically active fatty acids are 20 and 22 hydrocarbon chains which are known as arachidonic acid (20:4 n-6), eicosapentaenoic acid (20:5 n-3, EPA) and docosahexaenoic acids (22:6 n-3, DHA). These fatty acids have important roles in human health relating to decreasing the risk of coronary heart disease, delaying the onset of neurological degeneration of ageing, decreases inflammation, tumour cell growth, optimizes visual signalling, improves insulin sensitivity and maintenance of bone mass. ${ }^{2}$

Fish is relatively a much better source of n-3 PUFA than other foods. ${ }^{3}$ The consumption rate of fish has manifold in recent years, an average per capita consumption of $9.9 \mathrm{~kg}$ in the $1960 \mathrm{~s}$ to above $20 \mathrm{~kg}$ in $2014 .^{4-6} \mathrm{~A}$ lot of emphases have also led on the enhancement of aquaculture production in recent years. Since catfishes and murrels fetch good market price and wide acceptability for their delicacy these have been suggested as a component of aquaculture by researchers in India. ${ }^{7}$

In the present study, we have investigated the proximate composition, fatty acid profile and lipid quality indices of four catfishes and two murrel species few of them are even endangered and threatened according to the IUCN red list status (Table 1). The nutrition status of the species will definitely motivate for conservation and propagation of their culture.

Table I Introduction to the cat fishes and murrels studied in the present experiment

\begin{tabular}{|c|c|c|c|c|c|}
\hline Species & Classification & Environment & Biology & Food habit & $\begin{array}{l}\text { IUCN Red } \\
\text { List Status }\end{array}$ \\
\hline${ }^{12} \mathrm{WA}$ & $\begin{array}{l}\text { Siluriformes, } \\
\text { Siluridae }\end{array}$ & $\begin{array}{l}{ }^{\mathrm{I}} \mathrm{FW},{ }^{2} \mathrm{BW},{ }^{3} \mathrm{D}, \\
{ }^{4} \mathrm{PD},{ }^{5} \mathrm{~T}\end{array}$ & $\begin{array}{l}\text { A large, voracious and predatory } \\
\text { catfish, a pre-monsoon summer } \\
\text { breeder }\end{array}$ & $\begin{array}{l}\text { Juveniles feed mainly on insects; } \\
\text { adults feed on smaller fish, } \\
\text { crustaceans, and mollusks }\end{array}$ & ${ }^{8} \mathrm{NT}$ \\
\hline${ }^{13} \mathrm{OP}$ & $\begin{array}{l}\text { Siluriformes, } \\
\text { Siluridae }\end{array}$ & $\begin{array}{l}{ }^{\mathrm{F}} \mathrm{FW},{ }^{3} \mathrm{D},{ }^{4} \mathrm{PD}, \\
{ }^{5} \mathrm{~T} .\end{array}$ & $\begin{array}{l}\text { Adults inhabit clear as well as muddy } \\
\text { rivers, streams, ponds and lakes }\end{array}$ & $\begin{array}{l}\text { Omnivore, feeds on algae, roots } \\
\text { of some higher plants, protozoa, } \\
\text { small fishes and shrimps }\end{array}$ & NT \\
\hline${ }^{14} \mathrm{CG}$ & $\begin{array}{l}\text { Siluriformes, } \\
\text { Clariidae }\end{array}$ & 'FW, ${ }^{7} \mathrm{BP},{ }^{4} \mathrm{PD},{ }^{6} \mathrm{ST}$. & $\begin{array}{l}\text { Prefer shallow and swampy areas. } \\
\text { Widely tolerant of extreme } \\
\text { environmental conditions }\end{array}$ & $\begin{array}{l}\text { Feeds on insects, plankton, } \\
\text { invertebrates, fish, young } \\
\text { birds, rotting flesh and plants } \\
\text { preferably at night }\end{array}$ & ${ }^{9} \mathrm{NE}$ \\
\hline
\end{tabular}


Table Continued.

\begin{tabular}{|c|c|c|c|c|c|}
\hline Species & Classification & Environment & Biology & Food habit & $\begin{array}{l}\text { IUCN Red } \\
\text { List Status }\end{array}$ \\
\hline${ }^{15} \mathrm{PH}$ & $\begin{array}{l}\text { Siluriformes, } \\
\text { Pangasiidae }\end{array}$ & IFW, ${ }^{7} \mathrm{BP},{ }^{4} \mathrm{PD},{ }^{5} \mathrm{~T}$. & $\begin{array}{l}\text { Inhabits large rivers. } \\
\text { A migratory species }\end{array}$ & $\begin{array}{l}\text { Omnivorous feeding on fish } \\
\text { and crustaceans as well as on } \\
\text { vegetable debris }\end{array}$ & ${ }^{10} \mathrm{EN}$ \\
\hline${ }^{16} \mathrm{CS}$ & $\begin{array}{l}\text { Perciformes, } \\
\text { Channidae }\end{array}$ & $\begin{array}{l}{ }^{1} \mathrm{FW},{ }^{2} \mathrm{BW},{ }^{7} \mathrm{BP}, \\
{ }^{4} \mathrm{PD},{ }^{5} \mathrm{~T} .\end{array}$ & $\begin{array}{l}\text { Prefers stagnant and muddy water } \\
\text { of plains. Survive dry season by } \\
\text { burrowing in bottom mud of lakes, } \\
\text { canals and swamps }\end{array}$ & $\begin{array}{l}\text { Feed on fish, frogs, snakes, } \\
\text { insects, earthworms, tadpoles } \\
\text { and crustaceans }\end{array}$ & "LC \\
\hline${ }^{17} \mathrm{CP}$ & $\begin{array}{l}\text { Perciformes, } \\
\text { Channidae }\end{array}$ & $\begin{array}{l}{ }^{\mathrm{FWW}},{ }^{2} \mathrm{BW},{ }^{7} \mathrm{BP}, \\
{ }^{4} \mathrm{PD},{ }^{5} \mathrm{~T} .\end{array}$ & $\begin{array}{l}\text { Adults prefer stagnant waters in } \\
\text { muddy streams. Year round breeder }\end{array}$ & $\begin{array}{l}\text { Feed on worms, insects and } \\
\text { small fish }\end{array}$ & "LC \\
\hline
\end{tabular}

'FW, Freshwater; ${ }^{2} \mathrm{BW}$, Brackishwater; ${ }^{3} \mathrm{D}$, demersal; ${ }^{4} \mathrm{PD}$, Potamodromous; ${ }^{5} \mathrm{~T}$, Tropical; ${ }^{6} \mathrm{ST}$, Subtropical; ${ }^{7} \mathrm{BP}$, Benthopelagic; ${ }^{8} \mathrm{NT}$, Near Threatened; ${ }^{9} \mathrm{NE}, \mathrm{Not}$ evaluated; ${ }^{10} \mathrm{EN}$, Endangered; ' 'LC, Least concern; ${ }^{12} \mathrm{WA}$, Wallago attu; ${ }^{13} \mathrm{OP}$, Ompak pabda; ${ }^{14} \mathrm{CG}$, Clarias gariepinus; ${ }^{15} \mathrm{PH}$, Pangasidon hypopthalmus; ${ }^{16} \mathrm{CS}$, Channa striatus; ${ }^{17} \mathrm{CP}$, Channa punctatus

\section{Materials and methods}

\section{Sampling}

Twenty numbers of four different catfish species viz., Wallago attu (WA), Ompok pabda (OP), Clarias gariepinus (CG) and Pangasidon hypophthalmus (PH) and two different murrel species viz., Channa striatus (CS) and Channa punctatus (CP), were collected over five times from the local fish market of Bhubaneswar, Odisha India. These fish were caught from different water bodies such as rivers, canals, pools and ponds during the premonsonic season. The fresh fishes were kept inside the insulated box and brought to the laboratory. The weight and length of the individual fish were measured. The fish were immediately beheaded and gutted. Fins and scales, if any were removed and filleted. All the fillets for individual fish species were pooled for further processing.

\section{Proximate analysis}

Fish fillet moisture was determined by oven drying to constant weight at $105^{\circ} \mathrm{C}$ for $24 \mathrm{~h}$. Crude protein content was determined by Kjeldahl analysis (nitrogen $\times 6.25$; Kjeltec Autoanalyser, Vapodest-50, Gerhardt, Germany). Lipid was determined by chloroform: methanol (2:1) extraction. The ash content was determined by combustion of fillet samples in a crucible at $550^{\circ} \mathrm{C}$ for $4 \mathrm{hrs}$ in a muffle furnace. The gross energy content of fish fillet was determined using an adiabatic bomb calorimeter (IKA C5003, Staufen, Germany) and expressed as $\mathrm{Kcal} / \mathrm{g}$. All analyses were performed in accordance with the methods described by AOAC. ${ }^{8}$ All the samples were analyzed in triplicate to minimize the error.

\section{Fatty acid analysis}

Total lipids were extracted from $30 \mathrm{~g}$ of individual fresh fish samples. The flesh was homogenized by a mechanical stirrer with 15 volumes of chloroform-methanol $(2: 1 \mathrm{v} / \mathrm{v})$ mixture containing $0.01 \%$ butylated hydroxyl toluene (BHT). ${ }^{9}$ The weight of lipid was determined gravimetrically after evaporation of the solvent and fatty acid methyl esters (FAME) were prepared as described by Christie. ${ }^{10}$ Fatty acid methyl esters were analyzed by a gas chromatograph equipped with a flame-ionization detector (Shimadzu GC-2010, Kyoto, Japan) on a DB- 25 capillary column $(20 \mathrm{~m} \times 0.10 \mathrm{~mm}$ I.D., $0.10 \mu \mathrm{m} J \& W$ Scientific, Santa Clara, CA, USA). The detailed separation method was followed as per Pradhan et al. ${ }^{11}$ The chromatographic peaks in the samples were identified by comparing the relative retention times to the standard FAME peaks (Supelco 37 component FAME mix standard). Relative amount of each fatty acid methyl ester was expressed as a percentage of the total amount of fatty acids in the analyzed sample.

\section{Calculations}

The condition factor (CF) of the species were calculated by $\mathrm{CF}=$ weight/length ${ }^{3} \times 100$.

Lipid quality indices, i.e., atherogenic index (AI) and thrombogenicity index (TI), were calculated according to Ulbricht and Southgate. ${ }^{12}$

$A I=[12: 0+(4 x 14: 0)+16: 0] /[(P U F A n-6+n-3)+18: 1+$ other $M U F A]$

$$
T I=[14: 0+16: 0+18: 0] /[0.5 \times 18: 1+0.5 x o t h e r M U F A+0.5 x n-6 \text { PUFA+ } 3 x n-3 \text { PUFA+(n-3 PUFA/n-6 PUFA })] .
$$

Cholesterolemic index $(\mathrm{h} / \mathrm{H})$ was calculated as per Santos-Silva et al. ${ }^{13}$

$$
(h / H)=[C 18: 1 n-9+C 18: 2 n-6+C 18: 3 n-3++C 18: 3 n-6+C 20: 2 n-6+C 20: 3 n-6++C 20: 4 n-6+C 20: 5 n-3+C 22: 6 n-3] /[C 12: 0++C 14: 0 C 16: 0]
$$

\section{Statistical analysis}

Data were analyzed through one way analysis of variance using the SPSS (SPSS 16.0). The significant differences were considered significant at $\mathrm{P}<0.05$ among the species and Duncan multiple range (DMR) was applied to know the significance level.

\section{Results}

The average weight of $W$. attu, O. pabda, C. gariepinus, P. hypophthalmus, C. striatus and C. punctatus were $559.00 \pm 18.57 \mathrm{~g}$, $40.34 \pm 3.37 \mathrm{~g}, 335.00 \pm 32.86 \mathrm{~g}, 1740.00 \pm 86.49 \mathrm{~g}, 421.67 \pm 18.28 \mathrm{~g}$ and
$50.33 \pm 3.83 \mathrm{~g}$, respectively. The condition factors (CF) of all the species were evaluated. In the present study, $\mathrm{CF}$ of $C$. punctatus $(1.15 \pm 0.03)$ was significantly higher $(\mathrm{P}<0.05)$, whereas $W$. Attu exhibited significantly lower condition factor $(0.49 \pm 0.01)$ among the fishes (Table 2).

The proximate composition of the experimental fish is shown in Table 3. Among the six experimental species, the fillet of $C$. garipinus had the significantly lower $(\mathrm{P}<0.05)$ moisture content $(65.38 \pm 1.37 \%)$. The rest catfish and murrel species irrespective of their different size and weight exhibited similar fillet moisture content of around $74 \%$. 
Among catfishes, the fillet protein content of $W$. attu and P. sucthi were similar, around $20 \%$. However, significantly higher $(\mathrm{P}<0.05)$ fillet protein $(22.35 \%)$ was recorded in the murrel species, C. striatus. The lipid (13.45 $\pm 1.20 \%)$ and energy $(6.40 \pm 0.05 \mathrm{Kcal} / \mathrm{g})$ content of $C$. gariepinus was significantly higher $(\mathrm{P}<0.05)$ among the fish species. Murrels exhibited relatively lower fillet lipid content in comparison to catfishes. The fillet ash content of C. Punctatus (3.32\%) was significantly higher $(\mathrm{P}<0.05)$ among the experimental species.

In Table 4, the fatty acid (FA) profile of catfishes and murrels are reported. FA profiles showed the following distribution:
SFA $>$ MUFA $>$ PUFA. The total fillet saturated fatty acid (SFA) percentage of $C$. gariepinus was significantly lower $(\mathrm{P}<0.05)$ among the experimental fish species. The highest SFA $(54.03 \%)$ was obtained from the fillets of $C$. punctatus. The palmitic acid (C16:0, 19.49$29.52 \%$ ) was the most predominant fatty acid followed by stearic acid (C18:0, 5.61-8.63\%) and myristic acid (14:0, 1.41-6.12\%), presented the following distribution: $\mathrm{C} 16: 0>\mathrm{C} 18: 0>\mathrm{C} 14: 0$. However, in murrels the distribution pattern of predominant saturated fatty acids was C16:0 > C14:0 > C18:0.

Table 2 Biometry of the experimental catfishes and murrels

\begin{tabular}{lllllll}
\hline Attributes & 'WA & ${ }^{2}$ OP & ${ }^{3}$ CG & ${ }^{4}$ PH & ${ }^{5}$ CS & ${ }^{6}$ CP \\
\hline Avgwt $(\mathrm{g})$ & $559.00 \pm 18.57$ & $40.34 \pm 3.37$ & $335.00 \pm 32.86$ & $1740.00 \pm 86.49$ & $421.67 \pm 18.28$ & $50.33 \pm 3.83$ \\
Avg length $(\mathrm{cm})$ & $48.50 \pm 0.69$ & $18.74 \pm 0.60$ & $37.10 \pm 2.31$ & $56.60 \pm 1.19$ & $37.10 \pm 1.23$ & $16.20 \pm 0.45$ \\
Condition Factor & $0.49 \pm 0.01^{\mathrm{a}}$ & $0.60 \pm 0.03^{\mathrm{ab}}$ & $0.67 \pm 0.06^{\mathrm{ab}}$ & $0.96 \pm 0.02^{\mathrm{b}}$ & $0.84 \pm 0.05^{\mathrm{ab}}$ & $1.15 \pm 0.03^{\mathrm{bc}}$ \\
\hline
\end{tabular}

'Data are expressed as mean \pm SE of triplicate group of 20 fish of individual species. Values on the same row and different superscripts are significantly different $(\mathrm{P}<0.05)$. The difference in weight and length of the fish species being from different families were not analyzed statistically. 'WA, Wallago attu; ${ }^{2} \mathrm{OP}, \mathrm{Ompak}$ pabda; ${ }^{3} \mathrm{CG}$, Clarias gariepinus; ${ }^{4} \mathrm{PH}$, Pangasidon hypopthalmus; ${ }^{5} \mathrm{CS}$, Channa striatus; ${ }^{6} \mathrm{CP}$, Channa punctatus

Table 3 Fillet proximate compositions (\% on wet weight basis) of experimental catfishes and murrels'

\begin{tabular}{lllllll}
\hline Attributes & 'WA & ${ }^{2}$ OP & ${ }^{3}$ CG & ${ }^{4}$ PH & ${ }^{5}$ CS & ${ }^{6}$ CP \\
\hline Moisture & $74.72 \pm 0.42^{\mathrm{b}}$ & $73.92 \pm 0.27^{\mathrm{b}}$ & $65.38 \pm 1.37^{\mathrm{a}}$ & $74.92 \pm 0.50^{\mathrm{b}}$ & $74.57 \pm 0.48^{\mathrm{b}}$ & $74.31 \pm 0.25^{\mathrm{b}}$ \\
Crude Protein & $20.19 \pm 0.30^{\mathrm{c}}$ & $17.56 \pm 0.18^{\mathrm{a}}$ & $18.93 \pm 0.30^{\mathrm{b}}$ & $20.66 \pm 0.37^{\mathrm{c}}$ & $22.35 \pm 0.37^{\mathrm{d}}$ & $20.62 \pm 0.16^{\mathrm{c}}$ \\
Total Lipid & $3.53 \pm 0.36^{\mathrm{c}}$ & $6.76 \pm 0.17^{\mathrm{d}}$ & $13.45 \pm 1.20^{\mathrm{e}}$ & $3.35 \pm 0.90^{\mathrm{bc}}$ & $1.16 \pm 0.16^{\mathrm{a}}$ & $1.69 \pm 0.12^{\mathrm{ab}}$ \\
Ash & $1.62 \pm 0.06^{\mathrm{c}}$ & $1.83 \pm 0.06^{\mathrm{d}}$ & $1.40 \pm 0.02^{\mathrm{b}}$ & $1.10 \pm 0.05^{\mathrm{a}}$ & $1.56 \pm 0.06^{\mathrm{bc}}$ & $3.32 \pm 0.06^{\mathrm{e}}$ \\
Energy (Kcal/g) & $5.40 \pm 0.06^{\mathrm{b}}$ & $5.89 \pm 0.03^{\mathrm{c}}$ & $6.40 \pm 0.05^{\mathrm{d}}$ & $5.26 \pm 0.1 I^{\mathrm{b}}$ & $5.00 \pm 0.0 \mathrm{I}^{\mathrm{a}}$ & $4.91 \pm 0.04^{\mathrm{a}}$ \\
\hline
\end{tabular}

'Data are expressed as mean \pm SE of triplicate group of 20 fish of individual species. Values on the same row and different superscripts aresignificantly different (P<0.05). 'WA, Wallago attu; ${ }^{2} \mathrm{OP}$, Ompak pabda; ${ }^{3} \mathrm{CG}$,Clarias gariepinus; ${ }^{4} \mathrm{PH}$, Pangasidon hypopthalmus; ${ }^{5} \mathrm{CS}$, Channa striatus; ${ }^{6} \mathrm{CP}, \mathrm{Channa}$ punctatus

Table 4 Fatty acid profile (\% of total FA) of experimental catfishes and murrels'

\begin{tabular}{|c|c|c|c|c|c|c|}
\hline Fatty acids & 'WA & ${ }^{2} \mathrm{OP}$ & ${ }^{3} \mathrm{CG}$ & ${ }^{4} \mathrm{PH}$ & ${ }^{5} \mathrm{CS}$ & ${ }^{6} \mathrm{CP}$ \\
\hline $\mathrm{ClO}$ & $0.27 \pm 0.08 a$ & ND & ND & ND & $0.33 \pm 0.07 a$ & ND \\
\hline $\mathrm{Cll}$ & $0.72 \pm 0.07^{c}$ & $0.17 \pm 0.03^{a}$ & ND & ND & ND & $0.54 \pm 0.05^{b}$ \\
\hline $\mathrm{Cl} 2$ & $0.25 \pm 0.06 \mathrm{~b}$ & ND & ND & ND & $0.16 \pm 0.05 a$ & $0.22 \pm 0.02 b$ \\
\hline $\mathrm{Cl} 3: 0$ & $2.72 \pm 0.43^{b c}$ & $1.88 \pm 0.34^{b c}$ & $0.58 \pm 0.02^{\mathrm{a}}$ & $2.67 \pm 0.3 \mathrm{I}^{\mathrm{bc}}$ & $1.68 \pm 0.23^{b}$ & $2.87 \pm 0.18^{c}$ \\
\hline $\mathrm{Cl} 4: 0$ & $6.12 \pm 0.90^{\mathrm{ab}}$ & $2.47 \pm 1.14^{a}$ & $1.4 I \pm 0.36^{a}$ & $5.29 \pm 0.23^{\mathrm{ab}}$ & $10.22 \pm 2.47^{c}$ & $9.73 \pm 0.12^{\mathrm{bc}}$ \\
\hline CI5:0 & $1.40 \pm 0.26^{b}$ & $0.8 \mathrm{I} \pm 0.17^{\mathrm{ab}}$ & $0.17 \pm 0.00^{a}$ & $0.3 \mathrm{I} \pm 0.0 \mathrm{I}^{\mathrm{a}}$ & $1.18 \pm 0.18^{b}$ & $2.42 \pm 0.2 \mathrm{I}^{\mathrm{c}}$ \\
\hline $\mathrm{Cl} 6: 0$ & $24.44 \pm 0.6 \mathrm{I}^{\mathrm{bc}}$ & $25.78 \pm 1.33^{c}$ & $24.50 \pm 0.5 \mathrm{I}^{\mathrm{bc}}$ & $29.52 \pm 0.82^{\mathrm{d}}$ & $19.49 \pm 1.35^{\mathrm{a}}$ & $22.58 \pm 0.6 \mathrm{I}^{\mathrm{b}}$ \\
\hline CI7:0 & $0.75 \pm 0.28$ & $0.3 I \pm 0.04$ & ND & ND & $0.38 \pm 0.07$ & $0.73 \pm 0.20$ \\
\hline CI8:0 & $7.87 \pm 0.20^{b}$ & $7.89 \pm 0.47^{b}$ & $5.6 I \pm 0.07^{\mathrm{a}}$ & $7.99 \pm 0.36^{b}$ & $8.63 \pm 0.32^{b}$ & $8.57 \pm 0.84^{b}$ \\
\hline$C 20: 0$ & $1.19 \pm 0.28$ & $0.90 \pm 0.26$ & $1.03 \pm 0.49$ & I. $10 \pm 0.48$ & $2.73 \pm 1.06$ & $0.65 \pm 0.01$ \\
\hline$C 21: 0$ & $2.56 \pm 0.46$ & $2.10 \pm 0.27$ & $0.99 \pm 0.33$ & $0.19 \pm 0.01$ & $2.4 I \pm 0.62$ & $3.32 \pm 0.15$ \\
\hline C22:0 & $0.36 \pm 0.07 b$ & $0.19 \pm 0.02 \mathrm{a}$ & $0.45 \pm 0.03 c$ & & $0.22 \pm 0.06 a$ & $0.20 \pm 0.0 \mathrm{la}$ \\
\hline$C 23: 0$ & $1.66 \pm 0.19^{b}$ & $1.43 \pm 0.56^{\mathrm{b}}$ & $0.24 \pm 0.05^{\mathrm{a}}$ & $1.47 \pm 0.10^{\mathrm{b}}$ & $\mathrm{I} .6 \mathrm{I} \pm 0.4 \mathrm{I}^{\mathrm{b}}$ & $2.23 \pm 0.19^{b}$ \\
\hline C24:0 & ND & $0.63 \pm 0.32$ & ND & ND & ND & $0.15 \pm 0.02$ \\
\hline$\sum \mathrm{SFA}$ & $48.3 I \pm I .8 I^{\mathrm{bc}}$ & $42.87 \pm 4.93^{b}$ & $34.41 \pm 1.04^{\mathrm{a}}$ & $48.36 \pm 1.33^{\mathrm{bc}}$ & $47.19 \pm 2.55^{b}$ & $54.03 \pm 0.48^{c}$ \\
\hline CI4:I & $0.59 \pm 0.10 \mathrm{~d}$ & $0.5 \mathrm{I} \pm 0.06 \mathrm{~d}$ & $0.12 \pm 0.00 \mathrm{a}$ & ND & $0.33 \pm 0.07 b$ & $0.46 \pm 0.04 c$ \\
\hline CI5:I & $0.66 \pm 0.10 c$ & $0.44 \pm 0.00 \mathrm{a}$ & ND & ND & $0.58 \pm 0.12 b$ & ND \\
\hline
\end{tabular}

Citation: Pradhan C, Das DR, Mohanty TK, et al. Evaluation of nutritive value, fatty acid composition and lipid quality indices of freshwater catfishes and murrels. J Aquac Mar Biol. 2020;9(3):80-85. DOI: I0.I5406/jamb.2020.09.0028I 


\begin{tabular}{|c|c|c|c|c|c|c|}
\hline Fatty acids & 'WA & ${ }^{2} \mathrm{OP}$ & ${ }^{3} \mathbf{C G}$ & ${ }^{4} \mathbf{P H}$ & ${ }^{5} \mathrm{CS}$ & ${ }^{6} \mathrm{CP}$ \\
\hline CI6:I & $5.73 \pm 0.6 \mathrm{I}^{\mathrm{b}}$ & $5.63 \pm 0.38^{b}$ & $5.3 I \pm 0.28^{b}$ & $2.25 \pm 0.3 \mathrm{I}^{\mathrm{a}}$ & $3.96 \pm 0.70^{\mathrm{ab}}$ & $5.86 \pm 0.23^{b}$ \\
\hline CI7:I & $0.92 \pm 0.11 \mathrm{~d}$ & $0.7 I \pm 0.18 c c$ & $0.20 \pm 0.04 a$ & $0.48 \pm 0.02 b$ & $0.60 \pm 0.12 c$ & $1.00 \pm 0.14 d$ \\
\hline CI8:I & $17.98 \pm 1.20^{\mathrm{a}}$ & $27.98 \pm 1.48^{c}$ & $37.73 \pm 0.96^{d}$ & $30.63 \pm 1.23^{c}$ & $18.09 \pm 0.96^{\mathrm{a}}$ & $23.43 \pm 0.98^{b}$ \\
\hline C20:I & $2.12 \pm 0.63^{\mathrm{a}}$ & $1.06 \pm 0.28^{\mathrm{a}}$ & $2.49 \pm 0.90^{\mathrm{a}}$ & $2.54 \pm 1.60^{\mathrm{a}}$ & $11.62 \pm 2.00^{b}$ & $0.96 \pm 0.1 \mathrm{I}^{\mathrm{a}}$ \\
\hline$\sum$ MUFA & $27.77 \pm 0.88^{\mathrm{a}}$ & $35.62 \pm 1.16^{\mathrm{b}}$ & $45.70 \pm 1.35^{c}$ & $35.90 \pm 0.28^{\mathrm{b}}$ & $34.32 \pm 2.3 \mathrm{I}^{\mathrm{b}}$ & $31.23 \pm 0.52^{\mathrm{ab}}$ \\
\hline Cl8:2n6 & $6.98 \pm 0.80^{\mathrm{a}}$ & $11.12 \pm 1.32^{b}$ & $14.52 \pm 0.63^{c}$ & $7.94 \pm 0.48^{\mathrm{ab}}$ & $6.45 \pm 0.66^{a}$ & $6.35 \pm 0.13^{\mathrm{a}}$ \\
\hline Cl8:3n6 & $0.36 \pm 0.02 a$ & $0.48 \pm 0.10 \mathrm{~b}$ & $1.4 I \pm 0.16$ & $0.67 \pm 0.02 c$ & $0.36 \pm 0.04 a$ & $0.47 \pm 0.06 b$ \\
\hline$C 20: 2 n 6$ & $\mathrm{I} .10 \pm 0.3 \mathrm{Id}$ & $0.77 \pm 0.11$ & $0.29 \pm 0.08 \mathrm{a}$ & $0.66 \pm 0.02 c$ & $1.08 \pm 0.22 \mathrm{~d}$ & $0.39 \pm 0.0 \mathrm{lb}$ \\
\hline$C 20: 3 n 6$ & $1.69 \pm\left. 0.6\right|^{\mathrm{ab}}$ & $1.05 \pm 0.34^{\mathrm{ab}}$ & $1.42 \pm 0.15^{\mathrm{ab}}$ & $1.48 \pm 0.68^{\mathrm{ab}}$ & $3.03 \pm 1.04^{b}$ & $0.48 \pm 0.04^{\mathrm{a}}$ \\
\hline$C 20: 4 n 6$ & $0.66 \pm 0.2 \mathrm{lb}$ & $0.35 \pm 0.06 \mathrm{a}$ & $0.4 I \pm 0.16 \mathrm{a}$ & $0.90 \pm 0.02 c$ & $0.96 \pm 0.36 c$ & $0.5 \mathrm{I} \pm 0.04 \mathrm{bc}$ \\
\hline$\sum n-6$ PUFA & $10.56 \pm 1.40^{\mathrm{ab}}$ & $13.09 \pm 1.26^{\mathrm{b}}$ & $17.91 \pm 0.33^{c}$ & $11.65 \pm 1.08^{\mathrm{ab}}$ & $9.97 \pm 1.23^{\mathrm{ab}}$ & $7.40 \pm 0.36^{\mathrm{a}}$ \\
\hline $\mathrm{Cl} 18: 3 \mathrm{n} 3$ & $4.90 \pm 0.62^{b}$ & $3.60 \pm 0.28^{\mathrm{ab}}$ & $1.83 \pm 0.23^{\mathrm{a}}$ & $1.95 \pm 0.5 \mathrm{I}^{\mathrm{a}}$ & $3.98 \pm 0.65^{b}$ & $3.90 \pm 0.06^{b}$ \\
\hline$C 20: 3 n 3$ & $0.56 \pm 0.12 c$ & $0.29 \pm 0.04 a$ & ND & ND & $0.38 \pm 0.1 \mathrm{lb}$ & $0.29 \pm 0.0 \mathrm{la}$ \\
\hline$C 20: 5 n 3$ & $0.97 \pm 0.17^{b c}$ & $0.78 \pm 0.02^{b}$ & $0.27 \pm 0.07^{a}$ & $0.44 \pm 0.05^{\mathrm{ab}}$ & $1.19 \pm 0.19^{c}$ & $1.12 \pm 0.11^{\mathrm{c}}$ \\
\hline$C 22: 6 n 3$ & $5.53 \pm 0.24^{c}$ & $2.97 \pm 0.40^{\mathrm{b}}$ & $1.09 \pm 0.20^{\mathrm{a}}$ & $2.23 \pm 0.38^{\mathrm{ab}}$ & $6.27 \pm 0.60^{c}$ & $5.20 \pm 0.09^{c}$ \\
\hline$\sum$ n-3 PUFA & $\mathrm{II} .84 \pm 0.8 \mathrm{I}^{\mathrm{c}}$ & $7.49 \pm 0.68^{b}$ & $3.20 \pm 0.50^{\mathrm{a}}$ & $4.62 \pm 0.20^{\mathrm{a}}$ & $9.97 \pm 1.23^{c}$ & $10.4 \mid \pm 0.17^{c}$ \\
\hline$n-6: n-3$ & $0.89 \pm 0.03^{a}$ & $1.75 \pm 0.05^{\mathrm{ab}}$ & $5.60 \pm 0.18^{c}$ & $2.52 \pm 0.05^{b}$ & I. $10 \pm 0.07^{\mathrm{ab}}$ & $0.7 I \pm 0.04^{a}$ \\
\hline
\end{tabular}

MUFA, monounsaturated fatty acid; ND, not detected (zero values were excluded from the table); PUFA, polyunsaturated fatty acids; SFA, saturated fatty acid. 'The data are expressed as percentage of total fatty acids and average of three lots analyzed.Values reported are mean $\pm S E(n=3)$. Values of each feeding level with different superscript letters in the same row are significantly different $(\mathrm{P}<0.05) .{ }^{\prime} \mathrm{WA}$, Wallago attu; ${ }^{2} \mathrm{OP}, \mathrm{Ompak}$ pabda; ${ }^{3} \mathrm{CG}, \mathrm{Clarias}$ gariepinus; ${ }^{4} \mathrm{PH}, \mathrm{Pangasidon}$ hypopthalmus; ${ }^{5} \mathrm{CS}$, Channa striatus; ${ }^{6} \mathrm{CP}$, Channa punctatus

The total mono unsaturated fatty acids (MUFA) content ranged between 27.77 to $45.70 \%$. The lowest MUFA content was found in the muscle of $W$. attu and the highest in C. gariepinus. Olecic acid was the most prevalent MUFA.

In the n-6 PUFA, linoleic acid (C18:2n-6) was the major fatty acid with levels of 6.35 to $14.52 \%$ in the fillets of experimental species. Both the murrel species exhibited similar level of fillet n-6 PUFA. The parentomega-3 fatty acid, $\alpha$-linolenic acid (C18:3n-3, ALA) ranged between 1.83 to $4.90 \%$ in the studied species.

The ALA percentage of $C$. gariepinus and P. Hypophthalmus was alike and significantly lower $(\mathrm{P}<0.05)$ than that of other species studied. There was no variation $(\mathrm{P}>0.05)$ in fillet EPA and DHA percent between the murrel species. Among the fishes significantly

Table 5 Lipid quality indices of experimental catfishes and murrels'

\begin{tabular}{|c|c|c|c|c|c|c|}
\hline Lipid quality & 'WA & ${ }^{2} \mathrm{OP}$ & ${ }^{3} \mathrm{CG}$ & ${ }^{4} \mathrm{PH}$ & ${ }^{5} \mathrm{CS}$ & ${ }^{6} \mathrm{CP}$ \\
\hline Thrombogenic Index (IT) & $0.69 \pm 0.03^{\mathrm{ab}}$ & $0.75 \pm 0.03^{b}$ & $0.7 \mathrm{I} \pm 0.05^{\mathrm{b}}$ & $1.06 \pm 0.04^{c}$ & $0.59 \pm 0.07^{\mathrm{a}}$ & $0.66 \pm 0.02^{\mathrm{ab}}$ \\
\hline Athrogenic Index (IA) & $0.7 \mathrm{I} \pm 0.05^{\mathrm{b}}$ & $0.59 \pm 0.03^{\mathrm{ab}}$ & $0.40 \pm 0.0 \mathrm{I}^{\mathrm{a}}$ & $0.77 \pm 0.04^{b}$ & $0.67 \pm 0.1 \mathrm{I}^{\mathrm{b}}$ & $0.70 \pm 0.03^{b}$ \\
\hline Cholesterolemic index $(\mathrm{h} / \mathrm{H})$ & $1.30 \pm 0.03^{\mathrm{a}}$ & $1.74 \pm 0.04^{\mathrm{a}}$ & $2.28 \pm 0.04^{b}$ & $1.35 \pm 0.05^{\mathrm{a}}$ & $1.39 \pm 0.04^{\mathrm{a}}$ & $1.29 \pm 0.07^{\mathrm{a}}$ \\
\hline
\end{tabular}

'Values reported are mean $\pm S E(n=3)$. Values of each feeding level with different superscript letters in the same row are significantly different $(P<0.05)$. ${ }^{2}$ A, Wallago attu; ${ }^{2} \mathrm{OP}$, Ompak pabda; ${ }^{3} \mathrm{CG}$, Clarias gariepinus, ${ }^{4} \mathrm{PH}$, Pangasidon hypopthalmus; ${ }^{5} \mathrm{CS}$, Channa striatus; ${ }^{6} \mathrm{CP}$, Channa punctatus

\section{Discussion}

Condition factor (CF) is a biological index which depicts about the nutritional status, feeding intensity, age and growth rate of the fish. ${ }^{14}$ In the present study, the CF of $W . A t t u(0.49)$ was similar to lower $(\mathrm{P}<0.05)$ percentage of fillet EPA and DHA was recorded in $C$. gariepinus. The three species viz., $W$. attu, C. striatus and $C$. punctatus showed similar quantity $(\mathrm{P}>0.05)$ of total n-3 PUFA in their fillet where DHA was the predominant n-3 PUFA. The n-3 PUFA distribution in the experimental species was observed as DHA $>$ ALA $>$ EPA except C. gariepinus. The n-6/n3 ratio was recorded from 0.71 to 5.60 in the studied species.

The lipid quality indices viz., thrombogenic index (IT), athorogenic index (IA) and cholesterolemic index $(\mathrm{h} / \mathrm{H})$ was calculated for catfishes and murrels (Table 5). The IA and IT for the all the catfishes (except $P$. hypophthalmus) and murrels in the present experiment were below 1 and $\mathrm{h} / \mathrm{H}$ levels for all species were above 1. C. gariepinus exhibited significantly higher $(\mathrm{P}<0.05)$ cholesterolemic index $(\mathrm{h} / \mathrm{H})(2.28 \pm 0.04)$ in comparison to other fish species. 
the present study. Similarly, the catfishes and murrels of the present study showed CF same to that of catfishes and murrels from Asian and African region reported in preceding studies. ${ }^{17,18}$

The fillet moisture content of $C$. gariepinus was the lowest among the species studied and because of inverse correlation between moisture and lipid, the highest amount of lipid was also obtained in C. gariepinus. The lipid content of the experimental species ranged between $1.16-13.45 \%$, categorizes the murrels as lean fish $(<2 \%$ fat $)$ and catfishes as medium-fat (4-8\%) fish except $C$. gariepinus which is a high fat $(>8 \%)$ fish. ${ }^{19}$ According to the classification on the basis of tissue protein content by Stansby ${ }^{20}$ these experimental species can be considered as the high protein content fish. Among the catfishes, Wallago attu is considered having more nutritive value. ${ }^{21}$ In the present experiment, the highest fillet protein was obtained from $C$. striatus and fillet protein of $C$. punctatus was that of $W$. attu. This indicated that channa species have superiority in protein retention efficiency over catfishes.

The SFA percentage in the fillets of the fish species of the present experiment is almost up to $50 \%$ of the total fatty acid except $C$. gariepinus $(34.41 \%)$ which exhibited the lowest SFA in comparison to other catfishes as well as murrels. In general, fish are relatively low in SFAs $(<30 \%)$, other than certain species. ${ }^{22}$ However, in the present experiment all the six species studied exhibited more than $30 \%$ SFA which agrees with $40.17 \%$ SFA value in $W$. attu from Indus River, ${ }^{23} 42.63 \%$ SFA in muscles of farmed Tra catfish (Pangasius hypophthalmus) from Vietnam, ${ }^{24} 48.3-57.4 \%$ SFA in muscles of wild caught $C$. striatus from Malaysia. ${ }^{25}$ In this work, the FA distribution for catfishes and murrels are SFA $>$ MUFA $>$ PUFA. This result is in agreement with the data presented on US cultivated catfish. ${ }^{26}$

In other wild caught catfishes, C. Macrocephalus and Pangasius bocourti, 20-35\% MUFA content has been reported in their muscle ${ }^{27,28}$ which matches with the present observation of the experimental species except C. Gariepinus $(45.70 \%)$. MUFA is the preferred metabolic energy source reported earlier in other fish species. ${ }^{11}$ In this experiment, $W$. attu exhibited the lowest MUFA content. A possible explanation for this finding is that MUFA might have spent for different bodily process like tissue ogenesis, metamorphosis, fast growth, and basal metabolism agrees with the observation of Abi-Ayadet al. ${ }^{29}$ However, less fillet SFA than MUFA in C. gariepinus indicated the ability for efficient utilization of SFA over MUFA. MUFA has also several health benefits for human being like lowering cardiovascular disease, ${ }^{30}$ lowering cancer, ${ }^{31}$ and controlling diabetics. ${ }^{32}$ Among PUFAs, the 18 carbon PUFAs (18:3n-3 and 18:2n-6) are very essential for normal physiological functions of freshwater fish. ${ }^{33}$ In this present experiment, the difference in total n-6 PUFA and n-3 PUFA was noticed which could be for several reasons like difference in feeding habit, fishing ground, season, food availability, water temperature, age and size of the fish and the maturation status. ${ }^{34-36}$ The highest fillet n- 6 PUFA was recorded in the fillets of $C$. gariepinus and the lowest was in the fillets of $C$. punctatus. C. gariepinus may be pond grown with supply of artificial diet or poultry offal which is a very common way of culture of this species. ${ }^{37}$ The culture method could be the reason for highest content of fillet n-6 PUFA in C. gariepinus. The total fillet n-3 PUFA, EPA and DHA content in W. attu and two murrel species were similar and highest among the fish species. Bibi et al. ${ }^{38}$ reported almost similar amount of muscle EPA and DHA in large W. Attu from Pakistan. Channa species are very efficient in storing DHA evidenced from the study conducted by Aliyu-Paiko et al. ${ }^{25}$ and found up to $13.3 \%$ DHA in the wild caught Channa striata which is almost double than that found in the present study. The $n-6 / n-3$ ratio of fatty acids in fish is an important nutritional indicator. The ratio of $n-6 / n-3$ PUFAs of total lipids of freshwater fishes ranges between 0.5 and $3.8 .{ }^{40}$ In this present study, n-6/n-3 ratios in five species except $C$. gariepinus were below 4.0, suggested beneficial for human health.$^{41}$

The lipid quality indices are the dietetic quality of lipids. The IA and IT for the all the catfishes except P. Hypophthalmus and murrels in the present experiment were below 1 and $\mathrm{h} / \mathrm{H}$ levels for all species were above 1 , beneficial for human nutrition. Merdzhanova et al. ${ }^{42}$ reported similar IA (0.55), IT (0.53) and h/H (1.57) rates compared to our results in channel catfish (Ictalurus punctatus) from Bulgaria. These values are lower than those found in beef or chicken, indicating that the catfishes and murrels can be considered healthful food in terms of the risk of cardiovascular diseases. ${ }^{12}$

\section{Conclusion}

The results revealed that all the fish species studied in the experiment are good source of protein and unsaturated fatty acids with fairly high amount of n-3 fatty acids. Observing the fatty acid profile, W. attu, C. striatus and C. Punctatus can provide more EPA and DHA than that of O. Pabda, C. gariepinus and P. hypophthalmus. The n-6/n-3 ratios in five species except $C$. gariepinus were below 4.0 and considered beneficial for human nutrition. Overall, the lipid quality indices, IA, IT and $\mathrm{h} / \mathrm{H}$ were also in the suitable range for human health.

\section{Conflicts of interest}

The author declares that there is no conflict of interest.

\section{Acknowledgments}

The authors are very much thankful to the Director, Central Institute of Freshwater Aquaculture (CIFA) for providing financial and infrastructural facility for the experiment.

\section{Funding}

None.

\section{References}

1. Tacon AGJ, Metian M. Fish matters: importance of aquatic foods in human nutrition and global food supply. Reviews in Fisheries Science. 2013;21(1):22-23.

2. Calder PC, Yagoob P. Omega-3 polyunsaturated fatty acids and human health outcome. Bio Factors. 2009;35(3):266-272.

3. British Nutrition Foundation. Briefing Paper: $n-3$ Fatty Acids and Health London: British Nutrition Foundation. 1999

4. FAO. The State of World Fisheries and Aquaculture 2016. Contributing to Food Security and Nutrition for All. FAO Fisheries. Rome, Italy. 2016.

5. Sahoo SK, Giri SS, Chandra S, et al. Management in seed rearing of Asian Catfish, Clariasbatrachus, in hatchery conditions. Aquaculture Asia. 2010;16:23-25.

6. Kumar K, Lalrinsanga PL, Sahoo M, et al. Length-weight relationship and condition factor of Anabas testudineus and Channa species under different culture systems. World Journal of Fish and Marine Sciences. 2013;5(1):74-78.

7. Haniffa MA, Nagarajan M, Marimuthu K, et al. Embryonic and larval development of spotted murrel Channa punctatus. Indian Journal of fisheries. 2003;50(3):355-362.

8. AOAC. Official Methods of Analysis of the Association of the Official Analytical Chemists.16th edn. AOAC, Arlington, VA, USA. 1998. 
9. Folch J, Less, M, Stanley GH. A simple method for the isolation and purification of total lipids from animal tissues. Journal of Biological Chemistry. 1957;226:497-503.

10. Christie WW. Lipid analysis. In: Lipid Analysis. Christie WW editor. Pergamon Press, Oxford. 1982;17-23:51-61.

11. Pradhan C, Giri SS, Mohanty SN, et al. Effect of different feeding levels of plant-ingredient-based feed on fillet fatty acid profile, carcass trait, and sensory characteristics of Indian major carps in earthen pond polyculture. Journal of World Aquaculture Society. 2019;50 (2):374-389.

12. Ulbricht T, Southgate D. Coronary heart disease: seven dietary factors. Lancet. 1991;338(8773):985-992.

13. Santos-Silva JS, Bessa RJB, ad Santos FS. Effect of genotype, feeding system and slaughter weight on the quality of light lambs. II. Fatty acid composition of meat. Livestock. Science, 2002;77(2-3):187-194.

14. Oni SK, Olayemi JY, Adegboye JD. Comparative physiology of three ecologically distinct freshwater fishes, Alestes nurse Ruppell, Synodontisschall Bloch and S. schneider and Tilapia zilli Gervais. Journalof Fish Biology. 1983;22(1):105-109.

15. Thella R, Eldho PS, Ali A, et al. Length-weight relationship and condition factor of a large predatory catfish, Wallagoattu (schneider, 1801) from the rivers of central Kerala, India. Journal of Aquatic Biology and Fisheries. 2015;3:105-110

16. Gupta BK, Sarkar UK, Bhardwaj SK, et al. Condition factor, lengthweight relationships and length-length relationships of an endangered fish Ompokpabda (Hamilton) from river Gomti, a tributary of river Ganga, India. Journal of Applied Ichthyology. 2011;27(3): 962-964.

17. Getso BU, Abdullahi JM, Yola IA. Length-weight relationship and condition factor of Clariasgariepinus and Oreochromis niloticus of Wudilriver, Kano, Nigeria. Journal of Tropical Agriculture, Food, Environment and Extension. 2017;16(1):1-4.

18. Koundal A, Dhanze R, Sharma I. Length-weight relationship, condition factor and relative growth patterns of Channapunctata (Bloch) from Himachal Pradesh, India. Zoo's Print. 2014;XXIX,(1):25-29.

19. Haard NF. Control of chemical composition and food quality attributes of cultured fish. Food Research International. 1992;25(4):289-307.

20. Stansby ME. Chemical characteristics of fish caught in the northeast Pacific Ocean. Marine Fisheries Review. 1976;38(9):1-11.

21. Shendge AN, Pawar BA, Pandarkar AK. Variation in protein content of fresh water catfish Wallagoattu (Hamilton) in relation to sex and maturity cycle. Journal of Exerimental. Zoology India. 2012;15(1):251-252.

22. Ackman RG. Nutritional composition of fats in sea foods. Progress in Food Nutrition Science.1989;13(3-4):161-241.

23. Memon NN, Talpur FN, Bhanger MI. A Comparison of Proximate Composition and Fatty Acid Profile of Indus River Fish Species, International Journal of Food Properties. 2010;13(2):328-337.

24. Ho BT, Paul DR. Fatty acid profile of Tra Catfish (Pangasius hypophthalmus) compared to Atlantic Salmon (Salmo solar) and Asian Seabass (Lates calcarifer). International Food Research Journal. 2009;16:501-506.

25. Aliyu-Paiko M, Hashim R, Amuzat AO. Comparison of the whole body composition of fatty acids and amino acids between reared and wild snakehead fish Channastriata (Bloch 1793) Juveniles. Asian Fisheries Science. 2012;25:330-342.
26. Sathivel S, Witoon P, Grimm C, et al. Fatty acid composition of crude oil recovered from catfish viscera. Journal f American Oil Chemists 'Society. 2002;79(10):989-992.

27. Karapanagiotidis IT, Yakupitiyage A, Little DC, et al. The nutritional value of lipids in various tropical aquatic animals from rice-fish farming systems in northeast Thailand. Journal of Food Composition and Analysis. 2010;23(1):1-8.

28. Thammapat P, Raviyan P, Siriamornpun S. Proximate and fatty acids composition of the muscles and viscera of Asian catfish (Pangasius bocourti). Food Chemistry. 2010;122(1):223-227.

29. Abi-Ayad SMEA, Boutiba Z, Melard C, et al. Dynamics of total body fatty acids during early ontogeny of pikeperch (Sander lucioperca) larvae. Fish Physiology and Biochemistry. 2004;30:129-136.

30. Joris PJ, Mensink RP. Role of cis-monounsaturated fatty acids in the prevention of coronary heart disease. Current Atherosclerosis Reports. 2016;18(7):38.

31. Llor X, Pons E, Roca A, et al. The effects of fish oil, olive oil, oleic acid and linoleic acid on colorectal neoplastic processes. Clinical Nutrition. 2003;22(1):71-79.

32. Keapai W, Apichai S, Amornlerdpison D, et al. Evaluation of fish oilrich in MUFAs for anti-diabetic and antiinflammation potential in experimental type 2 diabetic rats. Korean Journal of Physiology and Pharmacology. 2016;20(6):581-593.

33. Bell MV, Tocher DR. In: Arts MT, Brett MT, Kainz ME, editors. Lipids in aquatic ecosystems. Springer, New York. 2009.

34. Bandarra NM, Batista I, Nunes ML, et al. Seasonal changes in lipid composition of sardine (Sardinapilchardus). Journal of Food Science. 1997;62(1):40-42.

35. Strobel C, Jahreis G, Kuhnt K. Survey of n-3 and n-6 polyunsaturated fatty acids in fish and fish products. Lipids in Health and Disease. 2012;11:144.

36. Gomes AD, Tolussi CE, Boëchat IG, et al. Fatty acid composition of tropical fish depends on reservoir trophic status and fish feeding habit. Lipids. 2016;51(10):1193-1206.

37. Matsiko SD, Mwanj MT. The current status of catfish culture and research in Uganda. In RW Ponzoni, NH Nguyen, editors. Proceedings of a Workshop on the Development of a Genetic Improvement Program for African Catfish Clarias gariepinus, Penang, World Fish Center Conference Proceedings No. 1889. 2008:57-63.

38. Bibi C, Khan A, Shah N, et al. Size dependent variation in cholesterol and fatty acids profile of different tissues of carnivore freshwater catfish, Wallagoattu. Pakistan Journal of Zoology. 2016;48(4):1017-1024.

39. Tocher D. Metabolism and functions of lipid and fatty acid in teleost fish. Reviews in Fisheries Science. 2003;11(2):107-184.

40. Simopoulos AP. The importance of the omega-6/omega-3 fatty acid ratio in cardiovascular disease and other chronic diseases. Experimental Biology and Medicine. 2008;233:674-688.

41. Wood JD, Enser M, Fisher AV, Nute GR, et al. Fat deposition, fatty acid composition and meat quality: A review. Meat Science, 2008;78:343-358.

42. Merdzhanova A, Dobreva D, Stancheva M. Quality evaluation of dietary lipid of channel catfish (Ictalurus punctatus) from Bulgaria. Bulgerian Journal of Agricultural science. 2015;21(1):202-207. 